\title{
Transketolase Is Identified as a Target of Herbicidal Substance $\alpha$-Terthienyl by Proteomics
}

\author{
Bin Zhao ${ }^{1,2}$, Jingqian Huo ${ }^{1}$, Ning Liu ${ }^{2}$, Jinlin Zhang ${ }^{1, *}$ and Jingao Dong ${ }^{2, *}$ \\ 1 College of plant protection, Agricultural University of Hebei, Baoding 071000, China; \\ bdzhaobin@126.com (B.Z.); huojingqian@163.com (J.H.) \\ 2 College of life science, Agricultural University of Hebei, Baoding 071000, China; lning121@126.com \\ * Correspondence: zhangjinlin@hebau.edu.cn (J.Z.); dongjingao@126.com (J.D.); \\ Tel.: +86-312-752-8575 (J.Z.); +86-312-752-8266 (J.D.)
}

Received: 28 November 2017; Accepted: 11 January 2018; Published: 12 January 2018

\begin{abstract}
Flaveria bidentis (L.) Kuntze. The bioassay presented here shows the strong herbicidal activity of $\alpha$-terthienyl on Digitaria sanguinalis, Arabidopsis thaliana and Chlamydomonas reinhardtii. The $\alpha$-terthienyl-induced response of $A$. thaliana at the protein level was analyzed at different times. Changes in the protein expression profiles were analyzed by two-dimensional gel electrophoresis and liquid chromatography tandem mass spectrometry (LC-MS/MS) mass spectrometry. Sixteen protein spots were identified that showed reproducible changes in the expression of at least 2-fold when compared to the control. Among these 16 spots, three were up-regulated and 13 were down-regulated. The decreased expression of several proteins associated with energy production and carbon metabolism suggested that these processes were affected by $\alpha$-terthienyl. To search for the candidate proteins in this screen, $A$. thaliana T-DNA mutants of the candidate proteins were used to test their susceptibility to $\alpha$-terthienyl. Amongst the others, attkl1, a mutant of transketolase, exhibited a significantly lower sensitivity to $\alpha$-terthienyl when hit compared with Col-0. Based on the identification of the proteins associated with the response to $\alpha$-terthienyl by proteomics, a candidate target protein transketolase was identified.
\end{abstract}

Keywords: $\alpha$-terthienyl; proteomics; herbicidal mechanism; transketolase

Key contribution: The mode of action of plant toxin $\alpha$-terthienyl is identified for the first time, and the target is validated as transketolase by two-dimensional gel electrophoresis. Transketolase is a good candidate target for hercide design.

\section{Introduction}

Since the initial description of 2,4-dichlorophenoxyacetic acid in 1942, many chemical herbicides have been developed and successfully applied in agriculture. As the mode of action (MoA) for these herbicides has been gradually elucidated, the structure and targets of herbicides have been characterized. Early MoA studies relied on physiological and biochemical technology such as the finding that glyphosate was a potent inhibitor of 5-enolpyruvyl-shikimic acid-3-phosphate synthase [1] or the demonstration that sulfonylurea herbicide was an extremely potent and selective inhibitor of acetolactate synthase [2,3]. The second phase of MoA research began in the 1990s. In this phase, the development of molecular biological techniques allowed the identification of nucleic acid mutations in target-resistant mutants [4] and the production of recombinant proteins for enzyme assays [5-7], facilitating MoA identification. In the third phase, 'omics' approaches were used to determine the mode of action of phytotoxins with previously unknown modes of action [8]. Including inquiries to the most fundamental MoAs to phenotypic responses, 'omics' approaches include transcriptomics, proteomics, metabolomics, physionomics, and phenomics. These strategies can be used to generate 
an abundance of data for compounds with known modes of action. Then, the response profile to a compound with an unknown mode of action is produced and compared with those for a known mode of action. As more plants have been sequenced, these types of 'omics' approaches have been used widely.

Proteomics is the large-scale study of proteins, particularly function and structure. Responses to external stimuli can be reflected at the protein level and analyzed by two-dimensional gel electrophoresis coupled with mass spectrometry. Currently, this approach is increasingly applied in biological science. Herbicides such as natural phytotoxins are expected to cause variations in protein expression level.

Our previous studies have showed that $9.25 \mathrm{mg} \alpha$-terthienyl could be extracted from $100 \mathrm{~g}$ root of Flaveria bidentis (L.) Kuntze [9]. The $\alpha$-terthienyl structural formula is shown in Figure 1 [10]. Some studies have demonstrated that $\alpha$-terthienyl has significant photoactivatable insecticidal activity in daylight or 300-400 nm UV light conditions [11-13]. $\alpha$-terthienyl is a type-II photosensitizer that is toxic toward a variety of insects, nematodes, micro-organisms, human blood cells and plants [14,15]. For example, low concentrations of $\alpha$-terthienyl in combination with UVA radiation can damage chloroplast membranes, interfere with enzymes in the Calvin Cycle, and inhibit photosynthetic $\mathrm{CO}_{2}$ fixation with light activation [16]. However, as an herbicidal activity component, $\alpha$-terthienyl has an unknown mode of action, identification the new target gene/protein will benefit pesticide creation. In this study, using a proteomic approach, we identified differentially expressed proteins (DEPs) that suggests the MoA of $\alpha$-terthienyl and found new herbicide targets as well.

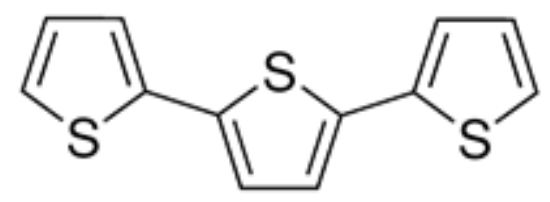

Figure 1. Structural formula of $\alpha$-terthienyl.

\section{Results}

\subsection{Herbicidal Activity of $\alpha$-Terthienyl on Plants}

In this study, the median inhibitory concentration $\left(\mathrm{IC}_{50}\right)$ was determined for $D$. sanguinalis, A. thaliana and C. reinhardtii as shown in Table 1. C. reinhardtii is a unicellular green alga, which has served as a model in molecular biology and photosynthesis research [17] including studies for various herbicides $[18,19] . \alpha$-terthienyl has a lower $\mathrm{IC}_{50}$ relative to atrazine for all plants tested. The $\mathrm{IC}_{50}$ of $\alpha$-terthienyl and atrazine in C. reinhardtii is 1.10 and $2.26(\mathrm{mg} / \mathrm{L})$, respectively. $\alpha$-terthienyl has a higher herbicidal activity than atrazine. The activity of $\alpha$-terthienyl was also tested in dark and light for $C$. reinhardti, as shown in the Figure S1, where the result shows that $\alpha$-terthienyl still retained activity in the darkness. Furthermore, Campbell [16] and Brennan [20] also reported the activity of $\alpha$-terthienyl on plants in dark, and Gommers [21] reported that it had a high activity on nematodes. It does seem that $\alpha$-terthienyl is capable of exerting toxic effects in the absence of light.

Table 1. The Herbicidal activity of $\alpha$-terthienyl on plants.

\begin{tabular}{cccc}
\hline Species/Treatment & Median Inhibitory Concentration $\mathbf{( m g / L )}$ & Toxicity Regression Equations & $\boldsymbol{R}^{\mathbf{2}}$ \\
\hline D. sanguinalis/ $\alpha$-terthienyl & 22.03 & $y=4.30+0.51 x$ & 0.9209 \\
D. sanguinalis/atrazine & 32.95 & $y=-3.09+2.02 x$ & 0.9162 \\
A. thaliana/ -terthienyl & 29.64 & $y=4.30+0.49 x$ & 0.9199 \\
A. thaliana/atrazine & 44.57 & $y=4.01+0.63 x$ & 0.9559 \\
C. reinhardti/ $\alpha$-terthienyl & 1.10 & $y=4.97+0.65 x$ & 0.9597 \\
C. reinhardti/atrazine & 2.26 & $y=4.78+0.63 x$ & 0.9778 \\
\hline
\end{tabular}




\subsection{Sample Extraction and Two-Dimensional Gel Electrophoresis}

Treatment time with $\alpha$-terthienyl is closely related with its effect as measured by two-dimensional gel electrophoresis. A. thaliana was examined after treatment with $\alpha$-terthienyl at $0.5 \mathrm{~h}, 2 \mathrm{~h}$, and $6 \mathrm{~h}$ by 2-DE. The high-resolution 2-DE gel pattern with a pI ranging from 4-7 was detected by coomassie brilliant blue (CBB) staining (Figure 2). More than 700 protein spots were detected in each CBB-stained gel by ImageMaster software. There were 848, 781, 708 and 768 protein spots detected after $\alpha$-terthienyl treatment at 0 h, $0.5 \mathrm{~h}, 2 \mathrm{~h}$, and $6 \mathrm{~h}$ respectively (gels shown in Figure 2A-D, respectively). Normalized protein spot volumes were determined for each 2-DE gel, and the number of proteins was inferred using a calibration curve based on different quantities of protein standards [22].

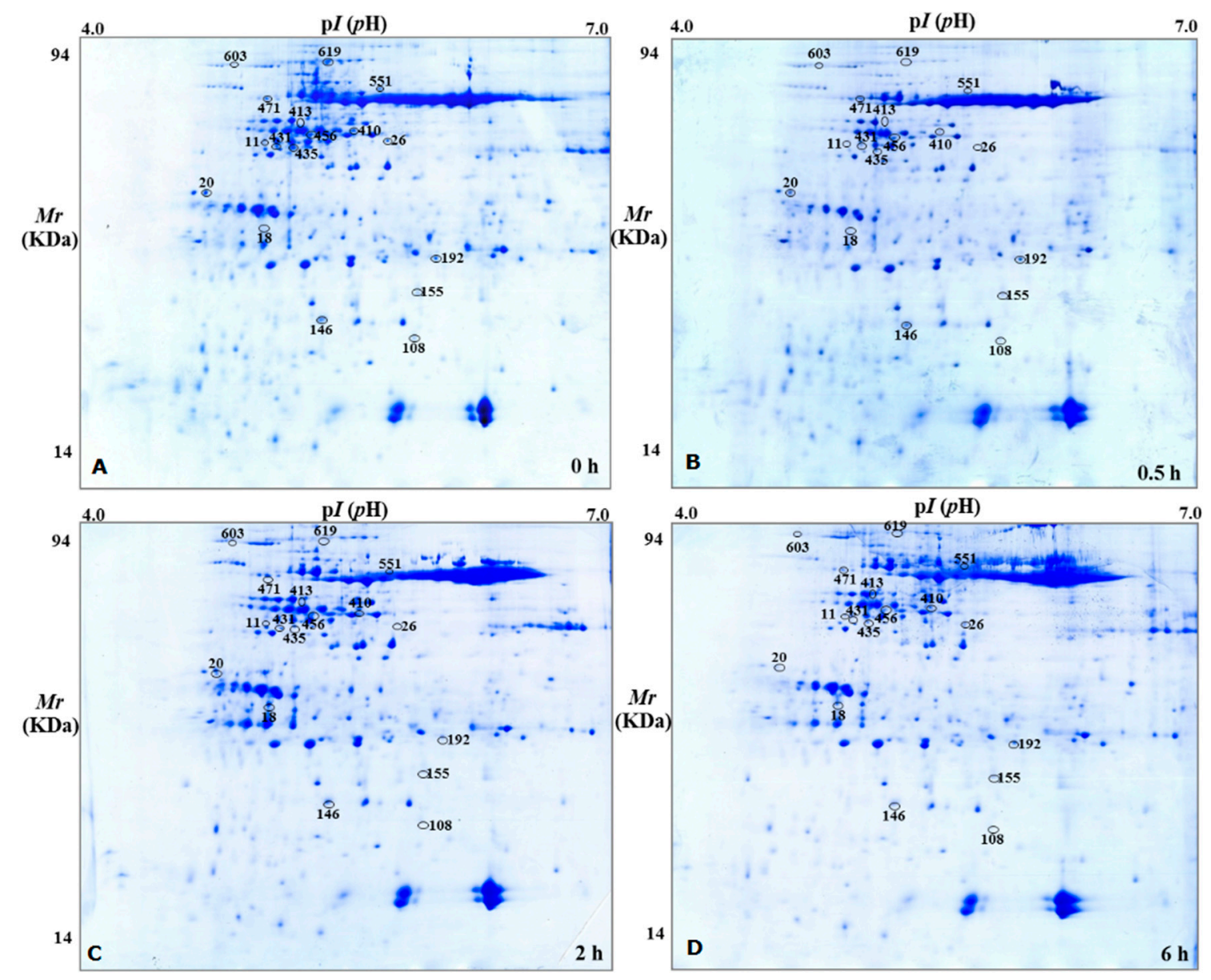

Figure 2. Distribution of expressed proteins (DEPs) in PAGE gel. (A) Treated by $\alpha$-terthienyl for 0 h; (B) treated by $\alpha$-terthienyl for $0.5 \mathrm{~h}$; (C) treated by $\alpha$-terthienyl for $2 \mathrm{~h}$; (D) treated by $\alpha$-terthienyl for $6 \mathrm{~h}$.

\subsection{Mass Spectrometry and Analysis of DEPS}

In this study, protein spots with at least 2-fold changes had excised from 2-DE and identified by Mass Spectrometry. Q Exactive, with high resolution, good stability, high sensitivity and rapid analysis was used to identify the protein. Through LC-MS/MS, 13 down-regulated proteins and three up-regulated proteins were identified in this study, which changed steadily after the treatment with $\alpha$-terthienyl. These proteins were involved in metabolism, transcription, translation, stress, and other processes. The expression of many kinds of proteins was inhibited after the treatment of $\alpha$-terthienyl such as spots $619,603,551,435,108,431,26,192,155,471,456$, and 20, while the expression of some proteins like spots 413,18 , and 11 were increased. From these 16 spots, two of them were identified 
the same one: spot 435 and 456. The protein expression level and description of DEPs are shown in Figure 3 and Table 2, respectively.
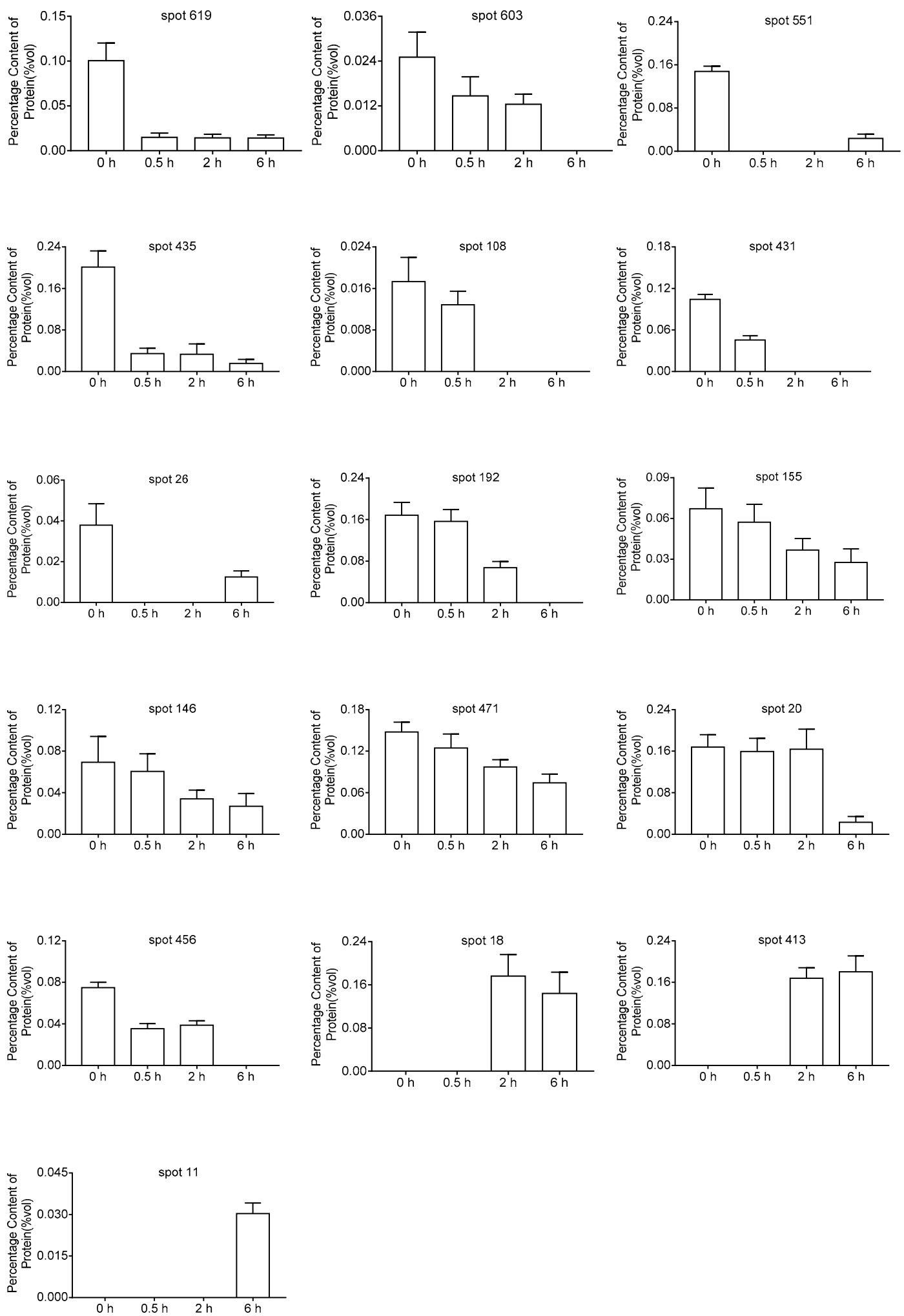

Figure 3. DEPs regulated by $\alpha$-terthienyl. 
Table 2. DEPs of $\alpha$-terthienyl-induced in A. thaliana identified by LC-MS/MS.

\begin{tabular}{|c|c|c|c|c|c|c|c|c|c|c|c|}
\hline \multirow[t]{2}{*}{ Spot ID } & \multirow[t]{2}{*}{ Biological Process } & \multirow{2}{*}{ Protein Name } & \multirow{2}{*}{ Gene No. } & \multirow{2}{*}{$\begin{array}{l}\text { Gene } \\
\text { Name }\end{array}$} & \multirow{2}{*}{$\begin{array}{c}\text { Coverage } \\
(\%)\end{array}$} & \multirow{2}{*}{$\begin{array}{c}\mathrm{pI} / M \mathrm{r} \\
\text { Experimental }\end{array}$} & \multirow{2}{*}{$\begin{array}{c}\mathrm{pI} / M \mathrm{r} \\
\text { Theoretical }\end{array}$} & \multicolumn{4}{|c|}{$\begin{array}{c}\text { Different Expression } \\
\text { Protein Detected by 2-DE }\end{array}$} \\
\hline & & & & & & & & $0 \mathrm{~h}$ & $0.5 \mathrm{~h}$ & $2 \mathrm{~h}$ & $6 \mathrm{~h}$ \\
\hline 619 & Carbohydrate metabolism & Transketolase-1 & AT3G60750 & ATTKL1 & 74 & $5.42 / 81$ & $5.94 / 80$ & 0 & $\downarrow$ & $\downarrow$ & $\downarrow$ \\
\hline 603 & defense response & heat shock cognate protein 70-1 & AT5G02500 & ATHSP70-1 & 71 & $4.95 / 77$ & $5.03 / 72$ & 0 & $\downarrow$ & $\downarrow$ & $\downarrow$ \\
\hline 551 & Energy metabolism & ATP synthase subunit beta & ATCG00480 & ATPB & 88 & $5.64 / 60$ & $5.38 / 54$ & 0 & $\downarrow$ & $\downarrow$ & $\downarrow$ \\
\hline 435 & reductive pentose-phosphate cycle & Phosphoribulokinase & AT1G32060 & PRK & 71 & $5.21 / 41$ & $5.71 / 44$ & $\bigcirc$ & $\downarrow$ & $\downarrow$ & $\downarrow$ \\
\hline 108 & Nucleotide and amino acid translation & Eukaryotic translation initiation factor $5 \mathrm{~A}-2$ & AT1G26630 & ATELF5A-2 & 72 & $5.83 / 18$ & $5.55 / 17$ & 0 & $\equiv$ & $\downarrow$ & $\downarrow$ \\
\hline 431 & Photosynthesis & Magnesium-chelatase subunit Chll-1 & AT4G18480 & CHLI1 & 66 & $5.21 / 46.5$ & $6.08 / 46.5$ & $\bigcirc$ & $\downarrow$ & $\downarrow$ & $\downarrow$ \\
\hline 26 & Energy metabolism & V-type proton ATPase subunit C & AT1G12840 & ATVHA-C & 81 & $5.68 / 41$ & $5.4 / 42$ & $\bigcirc$ & $\equiv$ & $\downarrow$ & $\downarrow$ \\
\hline 192 & Response to Stress & Glutathione S-transferase DHAR2 & AT1G75270 & DHAR2 & 81 & $5.97 / 25$ & $5.79 / 24$ & 0 & $\equiv$ & $\downarrow$ & $\downarrow$ \\
\hline 155 & translation & $60 \mathrm{~S}$ ribosomal protein $\mathrm{L} 5$ & ATMG00210 & RPL5 & 32 & $5.90 / 22$ & $5.6 / 21$ & 0 & $\equiv$ & $\downarrow$ & $\downarrow$ \\
\hline 146 & Protein transport & Vacuolar protein sorting-associated protein 25 & AT4G19003 & VPS25 & 26 & $5.30 / 20$ & $5.48 / 20$ & $\bigcirc$ & $\equiv$ & $\downarrow$ & $\downarrow$ \\
\hline 471 & Energy metabolism & ATP synthase subunit alpha & ATCG00120 & ATPA & 76 & $5.20 / 60$ & $5.19 / 55$ & 0 & $\equiv$ & $\downarrow$ & $\downarrow$ \\
\hline 20 & response to cadmium ion & 14-3-3-like protein GF14 upsilon & AT5G16050 & GRF5 & 78 & $4.72 / 32$ & $4.73 / 30$ & 0 & $\equiv$ & $\downarrow$ & $\downarrow$ \\
\hline 456 & reductive pentose-phosphate cycle & Phosphoribulokinase & AT1G32060 & PRK & 62 & $5.34 / 44$ & $5.71 / 44$ & 0 & $\equiv$ & $\equiv$ & $\downarrow$ \\
\hline 18 & Carbohydrate metabolism & Chlorophyll $\mathrm{a}-\mathrm{b}$ binding protein 2 & AT1G29910 & LHCB1.2 & 44 & $5.02 / 29$ & $5.29 / 28$ & $\bigcirc$ & $\equiv$ & $\equiv$ & $\uparrow$ \\
\hline 413 & Response to Stress & Myrosinase-binding protein & AT3G16470 & ATJAC1 & 69 & $5.26 / 48$ & $5.12 / 48$ & 0 & $\equiv$ & $\bar{\uparrow}$ & $\uparrow$ \\
\hline 11 & AMP salvage & Adenosine kinase 2 & AT5G03300 & ADK2 & 68 & $5.01 / 43$ & $5.14 / 38$ & 0 & $\equiv$ & $\equiv$ & $\uparrow$ \\
\hline
\end{tabular}




\subsection{The Gene Ontology and Protein-Protein Interaction Networks Analysis of DEPs}

The DEPs in Gene Ontology (GO) were mainly involved in the metabolic process, cellular components and catalytic activity in molecular functions (Figure S2). Therefore, we deem that $\alpha$-terthienyl could affect the expression of related enzymes in the metabolic process resulting in plant death. All those DEPs identified in the current study were submitted to STRING to assess the protein-protein interaction (PPI) networks (Figure 4). The network contained 15 nodes and 11 DEPs with an average node degree of 1.47 and a clustering coefficient of 0.3 . The PPI enrichment p-value was equal to 0.00322 and 0.000388 . The results showed that the ATTKL1 had a complex regulatory relationship with ATPB, PRK, ATELF5A-2 and ATHSP70-1, which participated in translation, energy metabolism, and defense response. Taken together, these results provide further evidence to support the mode of action for $\alpha$-terthienyl.

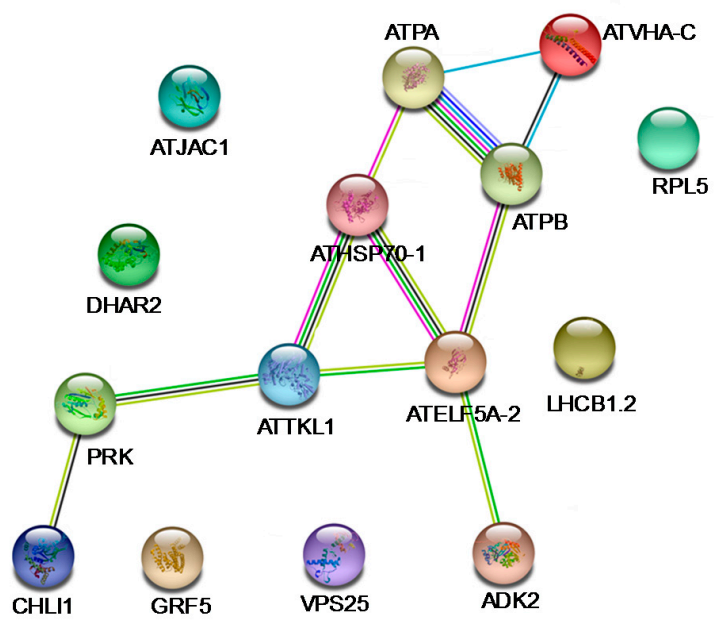

Figure 4. Protein-protein interaction regulatory network of DEPs. The regulatory network of DEPs was done using String software. Differentially regulatory network was represented by node. Different colors of lines represent different evidences for the predicted functional relationship between proteins; red line, gene fusions; dark blue line, gene co-occurrence; black line, co-expression; yellow line, text mining; green line, gene neighborhood; light blue line, database; and pink line, experimentally determined.

\subsection{Quantitative Real-Time PCR Analysis for DEPs}

After $\alpha$-terthienyl treatment, the RNA and protein expression of ATELF5A-2, PRK, VPS25 and $A T V H A-C$ were decreased, the RNA and protein expression of $A D K 2$ and DHAR2 were increased as shown in Figure 5. However, the measurements of RNA and protein expression of the ATTKL1 gene were not in accordance with each other. The ATTKL1 protein decreased, but the Quantitative Real-Time PCR (Q-PCR) analysis indicated a higher gene expression at the transcriptional level. This result may be explained by inhibition of protein activity caused by the binding of $\alpha$-terthienyl to the ATTKL1 protein, followed by an increase in ATTKL1 gene expression to compensate for the loss of protein activity (Figure 5).
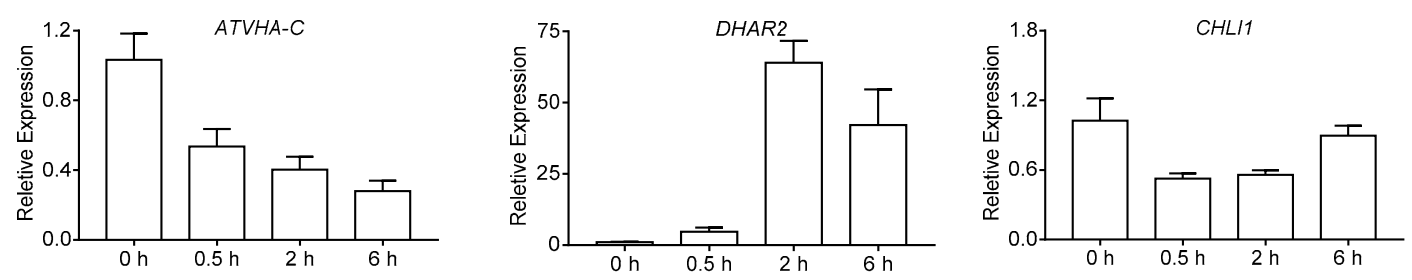

Figure 5. Cont. 

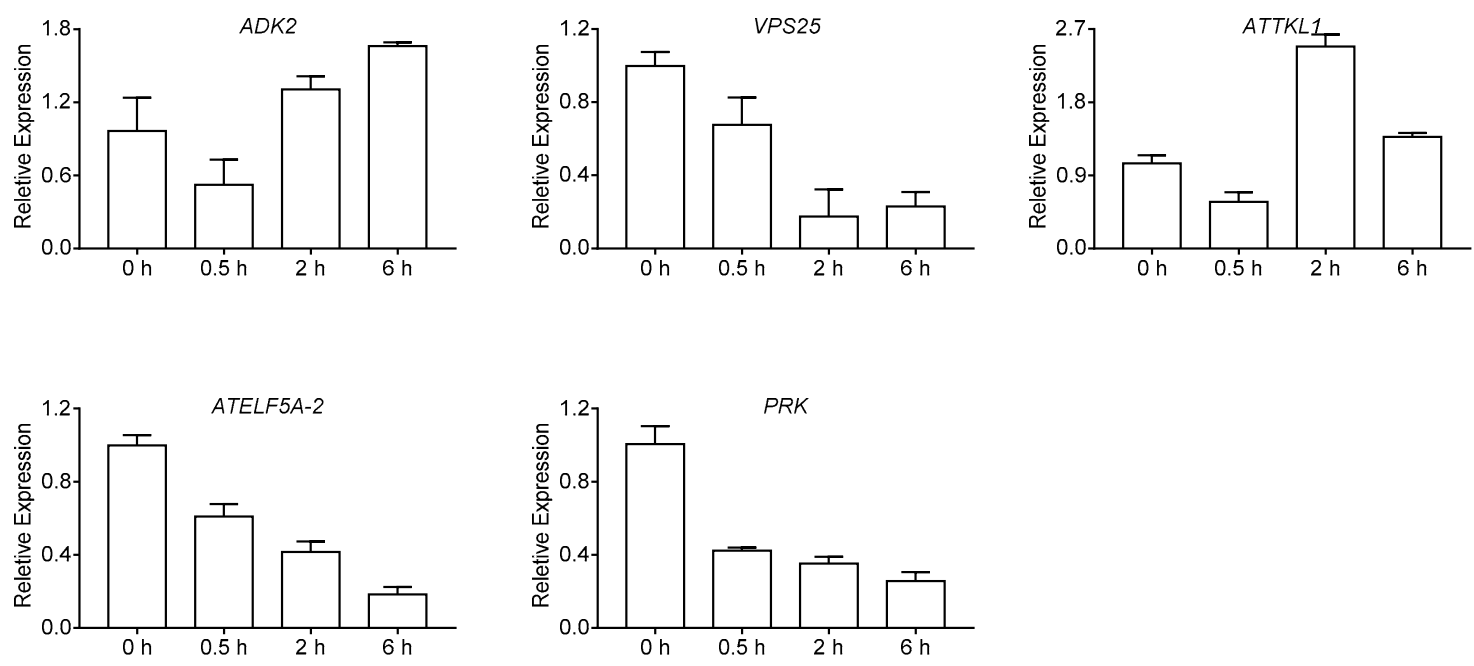

Figure 5. The identification of different expression proteins by Quantitative Real-Time PCR (Q-PCR).

\subsection{Transketolase Is One of Target Proteins Which Respond to $\alpha$-Terthienyl}

The homozygous of mutants prk, attkl1, chli1 and at $v h a-c$ were indentified by Three Primers-PCR (TP-PCR, Figure S3). Those mutants were tested by drug sensitivity. The results showed that the Col-0 and the mutants exhibited wilting death except attkl1 (SAIL_58D02) (Figure 6). The attkl1 had short stems and leaves when compared with the wild type, but after the treatments, it did not exhibit wilting death phenomenon, which presumably was due to the insertion of T-DNA. The T-DNA was inserted in the first exon of attkl1, the gene structure of which is shown in Figure S4. The primary structure of ATTKL1 protein will be frameshift or insertion mutated due to the insertion of T-DNA, which can decrease the affinity between the small molecules compounds and the protein. Hence, we inferred that $\alpha$-terthienyl could interact with ATTKL1, when the gene was mutated, following with the change of encoded protein leading to a failure combination of $\alpha$-terthienyl with the protein ATTKL1. In summary, the ATTKL1 protein was considered as a candidate protein, and was analyzed and verified in the next step. It plays a central role in the Calvin cycle of plant photosynthesis, its activity is a limiting factor of the photosynthetic rate. A slight decline of transketolase activity can reduce the plant growth rate and suppress the metabolites of aromatic amino acids and phenylalanine. Indeed, studies of transketolase mutant in tobacco have shown that small decreases in TKL can cause erythrose 4-phosphate levels to reduce, leading to photosynthesis inhibition and a significant decrease in soluble phenylpropanoids and aromatic amino acids [23]. Transketolase activity was tested with $\alpha$-terthienyl of different concentrations, and transketolase activity decreased gradually with the concentration increasing of $\alpha$-terthienyl (Figure 7). Results showed that transketolase activity in the wild type strain was more sensitive than that of the mutant. Indeed, there were two highly conserved paralogues of TKL, ATTKL1 and ATTKL2 in A. thaliana, which were predicted to reside in the chloroplast [24]. The homology of ATTKL1 and ATTKL2 were up to $88.26 \%$ (data not shown), both contained 740 amino acids. Nevertheless, only ATTKL1 was expressed in the highest levels in photosynthetic tissue ubiquitously. Unlike ATTKL1, ATTKL2 was expressed in development playing an important role in carbon allocation [24]. This caused the binding of $\alpha$-terthienyl to diminish while some enzymatic activity retained in attkl1. 

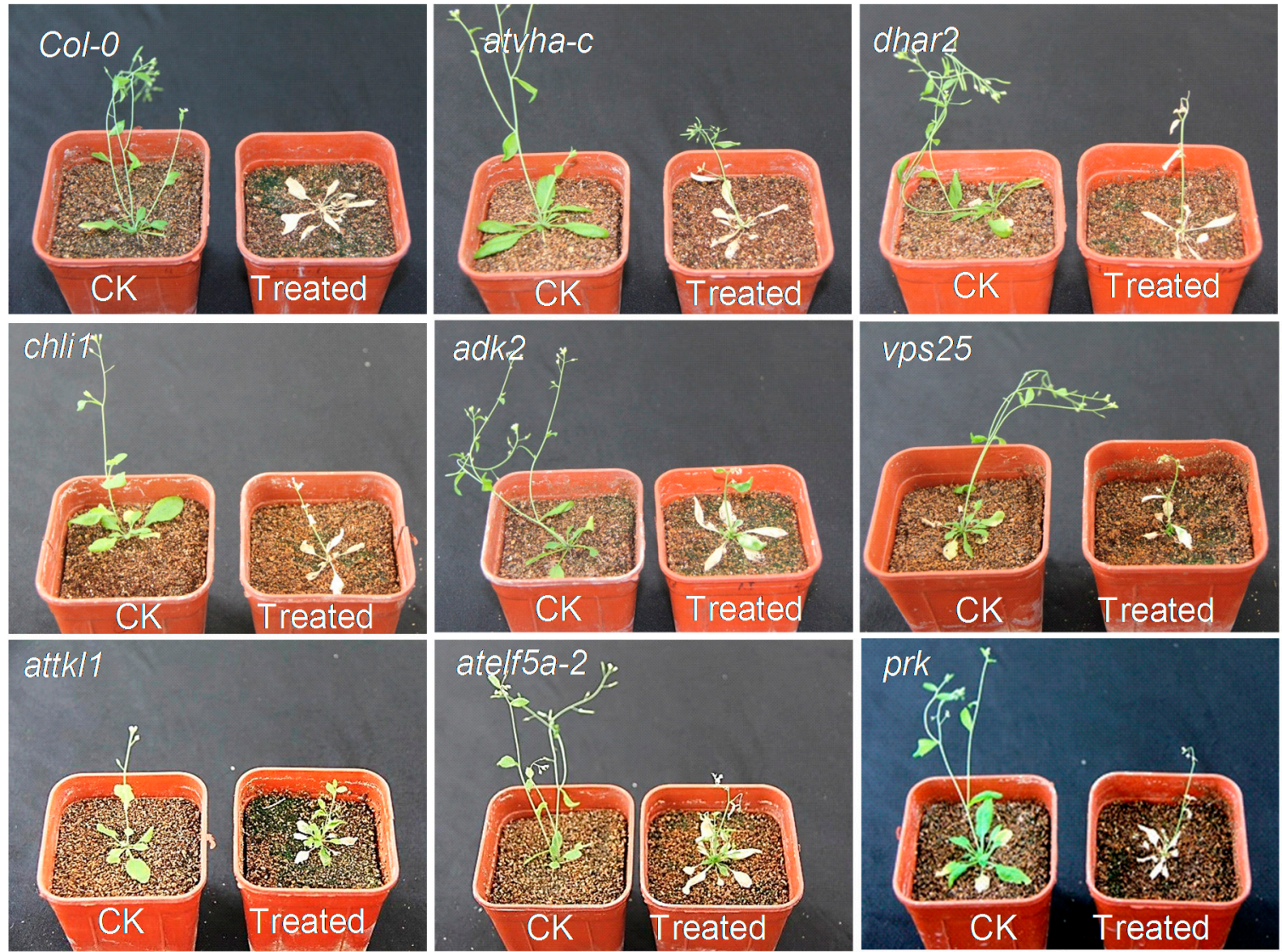

Figure 6. The sensitivity of Arabidopsis mutant to $\alpha$-terthienyl.

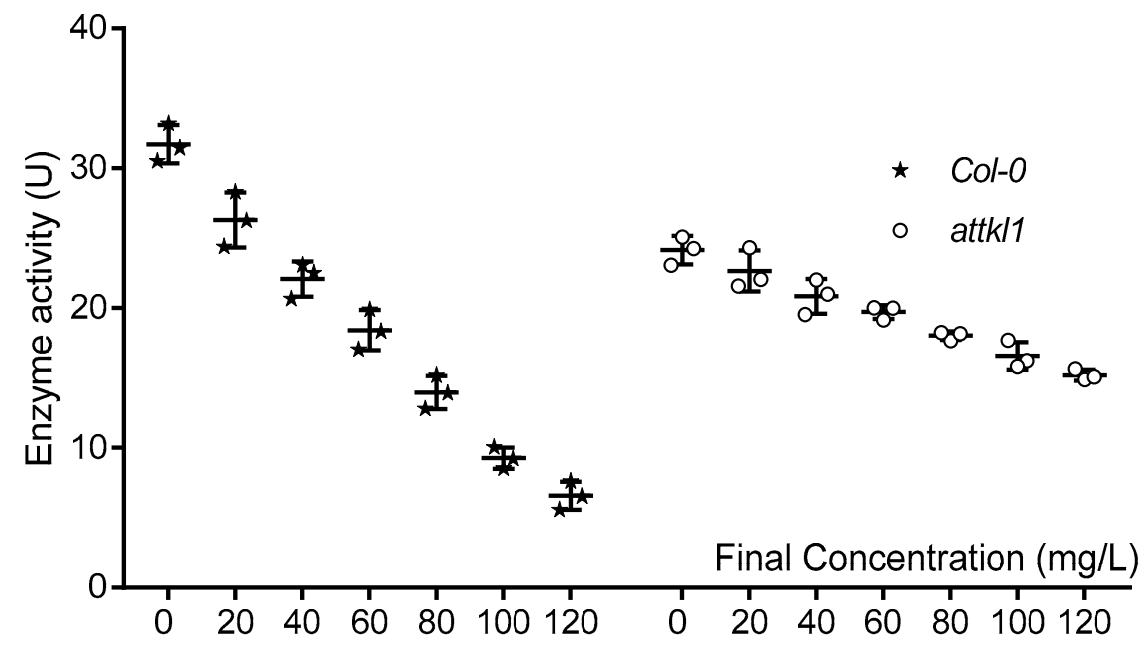

Figure 7. The enzyme activity of Col-0 and attkl1 which was treated by $\alpha$-terthienyl.

\section{Discussion}

\subsection{Proteomic Approach is a Powerful Tool for Identification the Mode of Action of Herbicide}

There are many reports of the identification of DEGs with Proteomic approach. Nestler et al. [25] tested the proteome of the green alga C. reinhardtii after treatment with low and high doses of norflurazon and diuron. Approximately 149-254 significantly altered proteins were found, and some were associated with specific modes of action. For example, the 1-deoxy-D-xylulose 5-phosphate 
synthase of the plastidic isoprenoid pathway were upregulated when C. reinhardtii was treated with norflurazon. For diuron, the target PS II-D1 protein was changed. Holmes et al. [26] used two dimensional gels to analyze the roots and meristem tissues of Medicago truncatula treated with acetolactate synthase (ALS) inhibiting herbicides. Eighty-one protein spots and 51 protein spots were changed in meristematic and nonmeristematic tissues, respectively.

In this study, two-dimensional gels were used to identify DEPs with different treatment times of $\alpha$-terthienyl on $A$. thaliana. Some proteins which play important role in plants developments and growth were identified. Such as Spot ID 619 was identified as transketolase (ATTKL1), and was down-regulated more than 3-fold in all treatments. The amount of protein was rapidly reduced when A. thaliana was treated with $\alpha$-terthienyl. Transketolase, presented in all organisms, is a key enzyme in the pentose phosphate pathway and the Calvin cycle of photosynthesis $[27,28]$. Thus, the transketolase plays an important role in plant defense and growth, making it a good herbicide target. At the $0.5 \mathrm{~h}$ post treatment with $\alpha$-terthienyl, the transketolase content rapidly decreased by approximately $90 \%$. The low level of transketolase should limit the efficiency of pentose phosphate pathway and calvin cycle, hindering the photosynthesis rate and resulting in plant death; Another is Spot 431, which was identified as magnesium-chelatase subunit Chll-1, an enzyme involved in chlorophyll biosynthesis $[29,30]$, catalyzing the insertion of magnesium ion into protoporphyrin IX to yield Mg-protoporphyrin IX. The reaction takes place in two steps with an ATP-dependent activation followed by an ATP-dependent chelation step. ChlI-1 possesses high affinity for ATP and may play a major role in chlorophyll biosynthesis. The plant could be etiolated when ChlI-1 levels were decreased or eliminated [31]; the other is Phosphoribulokinase (Spot 435) which catalyzes the ATP-dependent phosphorylation of ribulose-5-phosphate to ribulose-1,5-phosphate, a carbonate receptor of light synthesis and a key step in the pentose phosphate pathway, where carbon dioxide is assimilated by autotrophic organisms [32]. The phosphoribulokinase was down-regulated after $\alpha$-terthienyl treatment. Down-regulation of phosphoribulokinase can reduce the production of ribulose-1,5-phosphate, thus affecting photosynthesis and resulting in plant death.

Although we identified many proteins strongly affected by $\alpha$-terthienyl though 2 -DE, proteomic analysis was limited if the transcript information of gene (or protein) was not available in Genebank to identify the sequence of peptides. Another drawback is that proteomic approaches are limited to soluble proteins [33]. Recently, gel-free proteomic methods have been developed out isobaric tags for relative and absolute quantitation (iTRAG), and other protein tagging methods integrated with LC-MS/MS are likely to be powerful tools to overcome the limits of 2-D gel-based proteomics [34].

\section{2. $\alpha$-Terthienyl Can Inhibit Photosynthesis though Transketolase}

It is generally acknowledged that, $\alpha$-terthienyl has been developed as an effective photoactivated insecticide against pests, which can act on the cuticle enzymes, the midgut membranes, the neuromuscular sheath, and so on [35]. When the ovarian cells were exposed to $\alpha$-terthienyl, it changed the generation of oxidative stress, caused nonselective DNA damage which could increase apoptosis, G1 arrest and decrease cell population in S phase [36]. Another well-known example of toxicity in $\alpha$-terthienyl dependent on light is the killing of endoparasitic plant nematodes in the roots of Asteraceae [21]. Cilento proposed that the excited-state species generated as products of certain enzymatic reactions were capable of transferring excitation energy to other molecules such as chlorophyll and xanthene dyes. This indicates that it has a photochemistry mode and a photobiology mode in mode of action [37-40]. In addition, $\alpha$-terthienyl can exert toxic effects when in the absence of light, and it has some activity on plants and nematodes [41]. Furthermore, Brennan reported that $\alpha$-terthienyl could interfere the enzymes in Calvin cycle and inhibit photosynthetic $\mathrm{CO}_{2}$ fixation [16].

In this study, T-DNA mutants of $A$. thaliana were used for screening sensitive strains. Since the gene coding region is inserted by a long T-DNA fragment, it will inevitably lead to a big change in protein structure, which to a great extent may affect the binding of small molecules and proteins. Attkl1, a mutant of transketolase, was identified in this way. In our previous study, the molecular 
docking of ATTKL1 and $\alpha$-terthienyl was performed by computer simulation, where the results confirmed that $\alpha$-terthienyl was perfectly combined with ATTKL1. Furthermore, the fluorescence quenching spectroscopy also verified their combination [42]. We identified the key amino acids involved in the interaction between transketolase and $\alpha$-terthienyl. According to our previous study and the UniProt Archive database, the amino acid binding sites for ATTKL1 were His ${ }^{143}$, Gly ${ }^{234}$, Asn ${ }^{263}$, $\mathrm{Arg}^{434}, \mathrm{Ser}^{461}, \mathrm{Gln}^{488}, \mathrm{Phe}^{515}, \mathrm{His}^{539}, \mathrm{Asp}^{547}$ and $\mathrm{Arg}^{598}$ (Figure S5). The catalytic amino acids were $\mathrm{His}^{103}$ and $\mathrm{His}^{340}$. Our previous study showed that ATTKL1 can bind with $\alpha$-terthienyl using binding sites His ${ }^{143}, \mathrm{Gly}^{234}$, and the catalytic sites His ${ }^{103}$ and $\mathrm{His}^{340}$. According to the literature and our research results, we hypothesized that when the plants come into contact with $\alpha$-terthienyl, which can bind to the transketolase in the plant; it inhibited the active center of transketolase, rendering it unable to transfer Ketol to phosphate aldose, resulting in blocking of photosynthesis up to plant death.

All these results indicated that $\alpha$-terthienyl may firstly affect the activity of transketolase. Effects induced by $\alpha$-terthienyl will be studied in future studies, which will provide the foundation for characterizing the herbicidal mechanism and mode of action of $\alpha$-terthienyl. Additionally, this will provide a reference for discoveries of target sites of new pesticides.

\section{Conclusions}

This study analyzed the DEPs of $A$. thaliana after exposure to $\alpha$-terthienyl at different times, using two-dimensional gel electrophoresis. $\alpha$-terthienyl is a herbicidal active substance isolated from the Flaveria bidentis (L.) Kuntze. The results showed that 16 DEPs were identified. Among these proteins, 3 were up-regulated and 13 were down-regulated. Many of them were involved in photosynthesis respiration, energy synthesis, and metabolites synthesis. The accuracy of the protein data was verified by real-time quantitative PCR. The candidate protein ATTKL1 was found through the susceptibility testing of $\alpha$-terthienyl in A. thaliana T-DNA mutants. Based on the differential proteomic analyses and the relevant previously released data, we propose that the candidate protein transketolase could interact with $\alpha$-terthienyl. The results are of great theoretical significance for the creation of new pesticides.

\section{Materials and Methods}

\subsection{The Herbicidal Bioassay of $\alpha$-Terthienyl}

The effect of $\alpha$-terthienyl on D. sanguinalis, A. thaliana and C. reinhardtii was determined with the foliar treatment [43].

\subsection{Plant Material and Treatments}

A. thaliana Columbia (Col-0) was kindly provided by Dr. Xia of the Hong Kong Baptist University. Two-week-old $A$. thaliana plants were treated with $\alpha$-terthienyl at different times $(0 \mathrm{~h}, 0.5 \mathrm{~h}, 2 \mathrm{~h}$, and $6 \mathrm{~h})$; the $A$. thaliana treated at $0 \mathrm{~h}$ was used as a control, the aerial part samples were collected and kept at $-80^{\circ} \mathrm{C}$ and used for 2-DE.

\subsection{2-DE and Data Analysis}

A. thaliana proteins were extracted by trichloroacetic acid acetone (TCA-acetone) precipitation. The aerial parts of $A$. thaliana were triturated in liquid nitrogen with $10 \%$ polyvinylpolypyrrolidone (PVPP). The homogenates were lysed with precooled acetone (with 10\% TCA) in a centrifuge tube at $-20{ }^{\circ} \mathrm{C}$. The samples were centrifuged at $6000 \mathrm{~g}$ for $10 \mathrm{~min}$ at $4{ }^{\circ} \mathrm{C}$. Next, the pelleted material after centrifugation was rinsed twice with acetone and then sonicated for $5 \mathrm{~min}$ in $1 \mathrm{mM}$ Phenylmethanesulfonyl fluoride (PMSF), $2 \mathrm{mM}$ ethylenediaminetetraacetic acid (EDTA), and $10 \mathrm{mM}$ Dithiothreitol (DTT). The protein fractions were then obtained by centrifugation at $15,000 \mathrm{~g}$ for $20 \mathrm{~min}$. The protein concentration was determined using the RC-DC Protein Assay kit (Bio-Rad, Hercules, CA, USA) with BSA as the standard. 
Twenty-four cm Immobiline DryStrip Gels (pH 4-7, $130 \times 3 \times 0.5 \mathrm{~mm}$; Bio-Red) were used for isoelectric focusing with $700 \mu \mathrm{g}$ of total proteins (mixed in 2\% CHAPS, $18 \mathrm{mM}$ DTT, $0.8 \%$ IPG buffer with $350 \mu \mathrm{L}$ rehydration buffer). Rehydration and focusing were performed in an Ettan IPGphor II (GE Healthcare, LON, UK) at room temperature according to the following program: rehydration $8 \mathrm{~h} ; 50 \mathrm{~V}$ for $8 \mathrm{~h} ; 500 \mathrm{~V}$ for $1 \mathrm{~h} ; 1000 \mathrm{~V}$ for $1 \mathrm{~h} ; 8000 \mathrm{~V}$ for $2 \mathrm{~h}$; and $8000 \mathrm{~V}$ in 75,000 Vh. The immobilized $\mathrm{pH}$ gradient (IPG) strip was removed to a hydration disc after isoelectric focusing (IEF), and equilibrium and SDS-PAGE were performed according to the modified method of Giavalisco and Kamo [44]. The two-dimensional electrophoresis gels were stained with Coomassie Brilliant Blue as described in the Neuhoff method [45]. Each sample was analyzed with data from at least three experimental replicates.

\subsection{Image Acquisition and Data Analysis}

2-DE gels were stained by Coomassie Brilliant Blue (CBB) to image and analyze the data. Digitalized images of CBB-stained 2-DE gels were made using a high-resolution scanner (UMAX Powerlook 2100XL-USB, UMAX, Houston, TX, USA). The protein spots with increased or decreased intensity were detected and quantified with the ImageMaster software (ImageMaster 2D platinum 5.0; GE Healthcare, LON, UK) based on their relative volume. The amount of the protein spot was expressed as the volume of the spot, which was defined as the sum of the intensities of all the pixels of the spot. To compensate for subtle differences in sample loading, gel staining, and destaining, the volume of each spot was normalized as a percentage of the total volume of all of the spots present in the gel. The relative molecular mass $(\mathrm{Mr})$ and isoelectric point $(\mathrm{pI})$ of each protein were determined using 2-D SDS-PAGE standards after detection and matched by automated and manual editing. The DEPs which have at least 2-fold change were excised from the gels. Three replicates from three independent biological extracts were used for analysis.

\subsection{Proteins Identified by Mass Spectrometry}

Gel spots from 2-DE were carefully excised, successively destained, and dehydrated with destaining solution ( $50 \%$ methyl cyanides and $25 \mathrm{mM}$ ammonium bicarbonate). The proteins were incubated with $10 \mathrm{mM}$ DTT in $25 \mathrm{mM}$ ammonium bicarbonate at $56^{\circ} \mathrm{C}$ for $1 \mathrm{~h}$ and alkylated with $55 \mathrm{mM}$ iodoacetamide in $25 \mathrm{mM}$ ammonium bicarbonate at room temperature in dark for $45 \mathrm{~min}$, followed by the removal of surplus iodoacetamide. The gels were then washed twice in $25 \mathrm{mM}$ ammonium bicarbonate for $10 \mathrm{~min}$. Finally, the gel pieces were thoroughly washed and the methyl cyanides were removed in a Speedvac. The proteins were digested in modified trypsin solution $(67 \mu \mathrm{g} / \mathrm{mL}$ trypsin in $25 \mathrm{mM}$ ammonium bicarbonate) though incubation overnight at $37^{\circ} \mathrm{C}$. The gel pieces were extracted with $1 \mathrm{~mL}$ destaining solution for $30 \mathrm{~min}$ and dehydrated with $1 \mathrm{~mL}$ methyl cyanides. For LC-MS-MS, freeze-dried digestive products were dissolved in $0.1 \%$ formic acid. Digested peptides were separated on octadecylsilyl reverse-phase capillary columns $(5 \mu \mathrm{m}, 150 \AA$, Venusil $\times$ BPC; Agela Technologies, Tianjin, China) using the Ultimate 3000 LC system (Dionex, Sunnyvale, CA, USA). Flow was maintained at $0.4 \mu \mathrm{L} / \mathrm{min}$. Solvents A and B were 99.9/0.1 water/formic acid and 99.9/0.1 acetonitrile/formic acid, respectively, and were used for peptide elution. All digested peptides were analyzed by $\mathrm{Q}$ Exactive (Thermo Scientific, Waltham, MA, USA). Detailed instrument parameters were as follows, positive ion for ion mode, $70 \mathrm{~K}$ resolution for the full MS scans, $17.5 \mathrm{~K}$ resolution for the high energy collisional dissociation (HCD) MS/MS scans, and the mass spectrometer was operated under $1.8 \mathrm{kV}$ accelerating voltage in the reflectron mode with a $m / z$ range 600-4000. All MS and MS/MS spectra were obtained in profile mode. Raw LC-MS-MS data files were processed into peak lists in MGF format using Thermo Scientific Proteome Discoverer software version 1.3 (Thermo Scientific, Waltham, MA, USA). The results of the MGF files were searched using MASCOT (Matrix Science, Columbia, SC, USA) against the $A$. thaliana database (541,954 sequences; $192,668,437$ residues). These sequences of the DEPs were matched to cellular components, molecular functions, and biological processes as classified in the GO database. 


\subsection{RNA Extraction and Q-PCR Analysis}

The RNA of $A$. thaliana which has same treatment as protein extraction was isolated by using E.Z.N.A. ${ }^{\circledR}$ Plant RNA Kit (Omega, Irving, TX, USA), and mRNA was reversely transcribed into cDNA. Q-PCR was performed as the conventional method. The primers used for Q-PCR are shown in Table S1.

\subsection{The Sensitivity Test of $\alpha$-Terthienyl in T-DNA Mutants}

The T-DNA mutants associated with the DEPs were obtained from the A. thaliana Information Resource (TAIR) center. Those homozygous mutants were identified by TP-PCR [46] (the primer sequences are presented in Table S1) and cultured in vitro. The homozygous segregants mutants prk, attkl1, chli1 and at $v h a-c$ were identified by TP-PCR. However, $v p s 25$, adk2, atelf5a-2 and dhar 2 were not indentified as they were belonged to homozygous lines. After four weeks, the $A$. thaliana seedlings were treated with $100 \mathrm{mg} / \mathrm{L} \alpha$-thiophene or methanol to confirm the effects of drug treatment.

\subsection{Enzyme Activity Assay of Transketolase}

Plant tissue was ground in liquid nitrogen, then mixed with reaction liquid of $50 \mathrm{mmol} / \mathrm{L}$ Tris- $\mathrm{HCl}$ solution ( $\mathrm{pH} 7.8$ ), $0.2 \mathrm{mmol} / \mathrm{L}$ nicotinamide adenine dinucleotide, $1 \mathrm{mmol} / \mathrm{L}$ thiamine pyrophosphate, $2 \mathrm{mmol} / \mathrm{L}$ Ribose 5-phosphate, $10 \mathrm{mmol} / \mathrm{L} \mathrm{MgCl}_{2}$, and $2 \mathrm{mmol} / \mathrm{L}$ xylulose-5-phosphate. The enzymatic reaction was initiated by addition of $9 \mathrm{U}$ of triosephosphate isomerase and $3 \mathrm{U}$ of alpha glycerol dehydrogenase and after two minutes, the absorbance was measured at $340 \mathrm{~nm}$. The amount of enzyme required for the conversion of $1 \mu \mathrm{mol} \mathrm{NADH}$ in $1 \mathrm{~min}$ at $30^{\circ} \mathrm{C}$ was defined as a dynamic unit (U).

Supplementary Materials: The following are available online at www.mdpi.com/2072-6651/10/1/41/s1, Figure S1: The bioactivity of $\alpha$-terthienyl in light and darkness, Figure S2: The GO analysis of Differential expression proteins regulated by $\alpha$-terthienyl, Figure S3: Homozygous mutant identification, Figure S4: The gene structure of SAIL_58_D02, Figure S5: The analysis of key amino acid sites, Table S1: The primers for identification.

Acknowledgments: This work was supported by the National Nature Science Foundation of China (No. 31471786).

Author Contributions: The experiments were conceived and planned by Bin Zhao and Jingao Dong, the manuscript was written by Bin Zhao and Jinlin Zhang; experiments were performed by Bin Zhao, Jingqian Huo and Ning Liu. The final version of this manuscript has been read and approved by all authors.

Conflicts of Interest: The authors declare no conflict of interest.

\section{References}

1. Steinrucken, H.C.; Amrhein, N. The herbicide glyphosate is a potent inhibitor of 5-enolpyruvyl-shikimic acid-3-phosphate synthase. Biochem. Biophys. Res. Commun. 1980, 94, 1207-1212. [CrossRef]

2. LaRossa, R.A.; Schloss, J.V. The sulfonylurea herbicide sulfometuron methyl is an extremely potent and selective inhibitor of acetolactate synthase in Salmonella typhimurium. J. Biol. Chem. 1984, 259, 8753-8757. [PubMed]

3. Chaleff, R.S.; Mauvais, C.J. Acetolactate synthase is the site of action of two sulfonylurea herbicides in higher plants. Science 1984, 224, 1443-1445. [CrossRef] [PubMed]

4. Yamamoto, E.; Zeng, L.; Baird, W.V. Alpha-tubulin missense mutations correlate with antimicrotubule drug resistance in Eleusine indica. Plant Cell 1998, 10, 297-308. [CrossRef] [PubMed]

5. Lee, N.; Skerritt, J.H.; Thomas, M.; Korth, W.; Bowmer, K.H.; Larkin, K.A.; Ferguson, B.S. Quantification of the urea herbicide, diuron, in water by enzyme immunoassay. Bull. Environ. Contam. Toxicol. 1995, 55, 479-486. [CrossRef] [PubMed]

6. Riggle, B. Development of a preliminary enzyme-linked immunosorbent assay for the herbicide trifluralin. Bull. Environ. Contam. Toxicol. 1991, 46, 404-409. [CrossRef] [PubMed]

7. Odell, J.T.; Caimi, P.G.; Yadav, N.S.; Mauvais, C.J. Comparison of increased expression of wild-type and herbicide-resistant acetolactate synthase genes in transgenic plants, and indication of posttranscriptional limitation on enzyme activity. Plant Physiol. 1990, 94, 1647-1654. [CrossRef] [PubMed] 
8. Duke, S.O.; Bajsa, J.; Pan, Z. Omics methods for probing the mode of action of natural and synthetic phytotoxins. J. Chem. Ecol. 2013, 39, 333-347. [CrossRef] [PubMed]

9. Huo, J.Q.; Xing, J.H.; Zhang, L.H.; Kang, Z.H.; Zhang, J.L. Isolation and structural identification of herbicidal active substance from root of Flaveria bident (L.) kuntze. J. Integr. Agric. 2014, 13, 804-810. [CrossRef]

10. Bakker, J.; Gommers, F.J.; Nieuwenhuis, I.; Wynberg, H. Photoactivation of the nematicidal compound alpha-terthienyl from roots of marigolds (Tagetes species). A possible singlet oxygen role. J. Biol. Chem. 1979, 254, 1841-1844. [PubMed]

11. Chan, G.F.; Prihoda, M.; Towers, G.H.; Mitchell, J.C. Phototoxicity evoked by alpha-terthienyl. Contact Dermat. 1977, 3, 215-216.

12. Yamamoto, E.; MacRae, W.D.; Garcia, F.J.; Towers, G.H. Photodynamic hemolysis caused by alpha-terthienyl. Planta Med. 1984, 50, 124-127. [CrossRef] [PubMed]

13. Ji, H.F.; Shen, L. Triplet excited state characters and photosensitization mechanisms of alpha-terthienyl: A theoretical study. J. Photochem. Photobiol. B Biol. 2009, 94, 51-53. [CrossRef] [PubMed]

14. Downum, K.R. Light-activated plant defence. New Phytol. 2010, 122, 401-420. [CrossRef]

15. Campbell, G.; Lambert, J.D.; Arnason, T.; Towers, G.H. Allelopathic properties of alpha-terthienyl and phenylheptatriyne, naturally occurring compounds from species of asteraceae. J. Chem. Ecol. 1982, 8, 961-972. [CrossRef] [PubMed]

16. Brennan, T.M. Photosensitized inhibition of photosynthetic $14 \mathrm{CO}_{2}$ fixation by $\alpha$-terthienyl and Ultraviolet-A. Photochem. Photobiol. 2008, 59, 631-636.

17. Harris, E.H. Chlamydomonas as a model organism. Annu. Rev. Plant Physiol. Plant Mol. Biol. 2001, 52, 363-406. [CrossRef] [PubMed]

18. Fischer, B.B.; Rufenacht, K.; Dannenhauer, K.; Wiesendanger, M.; Eggen, R.I. Multiple stressor effects of high light irradiance and photosynthetic herbicides on growth and survival of the green alga Chlamydomonas reinhardtii. Environ. Toxicol. Chem. 2010, 29, 2211-2219. [CrossRef] [PubMed]

19. Jamers, A.; De, C.W. Effect assessment of the herbicide paraquat on a green alga using differential gene expression and biochemical biomarkers. Environ. Toxicol. Chem. 2010, 29, 893-901. [CrossRef] [PubMed]

20. Brennan, T.M. Decarboxylation of lndole-3-acetic acid and inhibition of growth in avena sativa seedlings by plant-derived photosensitizers. Photochem. Photobiol. 2010, 64, 1001-1006. [CrossRef]

21. Gommers, F.J.; Bakker, J. Mode of action of $\alpha$-terthienyl and related compounds may explain the suppressant effects of tagetes species on populations of free living endoparasitic plant nematodes. Bioact. Mol. 1988, 7 , 61-69.

22. Asirvatham, V.S.; Watson, B.S.; Sumner, L.W. Analytical and biological variances associated with proteomic studies of medicago truncatula by two-dimensional polyacrylamide gel electrophoresis. Proteomics 2002, 2, 960-968. [CrossRef]

23. Henkes, S.; Sonnewald, U.; Badur, R.; Flachmann, R.; Stitt, M. A small decrease of plastid transketolase activity in antisense tobacco transformants has dramatic effects on photosynthesis and phenylpropanoid metabolism. Plant Cell 2001, 13, 535-551. [CrossRef] [PubMed]

24. Rocha, A.G.; Mehlmer, N.; Stael, S.; Mair, A.; Parvin, N.; Chigri, F.; Teige, M.; Vothknecht, U.C. Phosphorylation of arabidopsis transketolase at ser428 provides a potential paradigm for the metabolic control of chloroplast carbon metabolism. Biochem. J. 2014, 458, 313-322. [CrossRef] [PubMed]

25. Nestler, H.; Groh, K.J.; Schonenberger, R.; Eggen, R.I.; Suter, M.J. Linking proteome responses with physiological and biochemical effects in herbicide-exposed Chlamydomonas reinhardtii. J. Proteom. 2012, 75, 5370-5385. [CrossRef] [PubMed]

26. Holmes, P.; Farquharson, R.; Hall, P.J.; Rolfe, B.G. Proteomic analysis of root meristems and the effects of acetohydroxyacid synthase-inhibiting herbicides in the root of Medicago truncatula. J. Proteome Res. 2006, 5, 2309-2316. [CrossRef] [PubMed]

27. Villafranca, J.J.; Axelrod, B. Heptulose synthesis from nonphosphorylated aldoses and ketoses by spinach transketolase. J. Biol. Chem. 1971, 246, 3126-3131. [PubMed]

28. Murphy, D.J.; Walker, D.A. The properties of transketolase from photosynthetic tissue. Planta 1982, 155, 316-320. [CrossRef] [PubMed]

29. Kobayashi, K.; Mochizuki, N.; Yoshimura, N.; Motohashi, K.; Hisabori, T.; Masuda, T. Functional analysis of Arabidopsis thaliana isoforms of the mg-chelatase chli subunit. Photochem. Photobiol. Sci. Off. J. Eur. Photochem. Assoc. Eur. Soc. Photobiol. 2008, 7, 1188-1195. [CrossRef] [PubMed] 
30. Rissler, H.M.; Collakova, E.; DellaPenna, D.; Whelan, J.; Pogson, B.J. Chlorophyll biosynthesis. Expression of a second chl $i$ gene of magnesium chelatase in arabidopsis supports only limited chlorophyll synthesis. Plant Physiol. 2002, 128, 770-779. [CrossRef] [PubMed]

31. Du, S.Y.; Zhang, X.F.; Lu, Z.; Xin, Q.; Wu, Z.; Jiang, T.; Lu, Y.; Wang, X.F.; Zhang, D.P. Roles of the different components of magnesium chelatase in abscisic acid signal transduction. Plant Mol. Biol. 2012, 80, 519-537. [CrossRef] [PubMed]

32. Gibson, J.L.; Chen, J.H.; Tower, P.A.; Tabita, F.R. The form ii fructose 1,6-bisphosphatase and phosphoribulokinase genes form part of a large operon in rhodobacter sphaeroides: Primary structure and insertional mutagenesis analysis. Biochemistry 1990, 29, 8085-8093. [CrossRef] [PubMed]

33. Trimpin, S.; Brizzard, B. Analysis of insoluble proteins. Biotechniques 2009, 46, 409-419. [CrossRef] [PubMed]

34. Bindschedler, L.V.; Cramer, R. Quantitative plant proteomics. Proteomics 2011, 11, 756-775. [CrossRef] [PubMed]

35. Huang, Q.; Yun, X.; Rao, W.; Xiao, C. Antioxidative cellular response of lepidopteran ovarian cells to photoactivated alpha-terthienyl. Pestic. Biochem. Physiol. 2017, 137, 1-7. [CrossRef] [PubMed]

36. Huang, Q.; Liu, Y.; Zhan, T.; Deng, Y.; He, Y. Comparable susceptibilities of human 293 cells and insect tn-5b1-4 cells to photoactivated alpha-terthienyl. J. Agric. Food Chem. 2010, 58, 2637-2642. [CrossRef] [PubMed]

37. Cilento, G.; Nascimento, A.L. Generation of electronically excited triplet species at the cellular level: A potential source of genotoxicity. Toxicol. Lett. 1993, 67, 17-28. [CrossRef]

38. Cilento, G.; Adam, W. Photochemistry and photobiology without light. Photochem. Photobiol. 1988, 48, 361-368. [CrossRef] [PubMed]

39. Cilento, G. Photobiochemistry without Light: Intracellular Generation and Transfer of Electronic Energy; Springer: Boston, MA, USA, 1988.

40. Grijalba, M.T.; Nantes, L.L.; Cilento, G.; Quina, F.H. Tris(bipyridine) ruthenium(ii): An efficient detector of excited species generated by chemiluminescent processes. Photochem. Photobiol. 1996, 63, 697-701. [CrossRef]

41. Brennan, T.M.; Lee, E.; Battaglia, P.R. Participation of the photosensitizer alpha-terthienyl in the peroxidase-catalyzed oxidation of indole-3-acetic acid. Photochem. Photobiol. 2000, 71, 355-360. [CrossRef]

42. Zhao, B.; Huo, J.; Xing, J.; Meng, Q.I.; Zhang, J.; Dong, J. Homologous modeling of transketolase ATTKL1 and its combination with $\alpha$-terthienyl in Arabidopsis thaliana. Chem. J. Chin. Univ. 2015, 36, 682-686.

43. Zhang, J.L.; Zhang, L.H.; Liu, Y.C.; Ma, J.; Li, C.; Dong, J.G. The herbicidal activity of mutant isolates from Botrytis cinerea. Agric. Sci. China 2006, 5, 622-628. [CrossRef]

44. Giavalisco, P.; Nordhoff, E.; Kreitler, T.; Kloppel, K.D.; Lehrach, H.; Klose, J.; Gobom, J. Proteome analysis of arabidopsis thaliana by two-dimensional gel electrophoresis and matrix-assisted laser desorption/ionisation-time of flight mass spectrometry. Proteomics 2005, 5, 1902-1913. [CrossRef] [PubMed]

45. Neuhoff, V.; Arold, N.; Taube, D.; Ehrhardt, W. Improved staining of proteins in polyacrylamide gels including isoelectric focusing gels with clear background at nanogram sensitivity using coomassie brilliant blue g-250 and r-250. Electrophoresis 1988, 9, 255-262. [CrossRef] [PubMed]

46. Liu, Y.G.; Mitsukawa, N.; Oosumi, T.; Whittier, R.F. Efficient isolation and mapping of Arabidopsis thaliana t-DNA insert junctions by thermal asymmetric interlaced PCR. Plant J. Cell Mol. Biol. 1995, 8, 457-463. [CrossRef]

(C) 2018 by the authors. Licensee MDPI, Basel, Switzerland. This article is an open access article distributed under the terms and conditions of the Creative Commons Attribution (CC BY) license (http://creativecommons.org/licenses/by/4.0/). 